УДК 373.3.011.3/.018.58(477)

С. Л. Яценко,

кандидат педагогічних наук, доцент

(Житомирський державний університет імені Івана Франка)

sl.yatsenko.gdu@gmail com

ORCID: 0000-0002-9646-8841

\title{
АРТ-ТЕРАПІЯ ЯК ЗАСІБ ГАРМОНІЗАЦІЇ ПРОФЕСІЙНОГО СЕРЕДОВИЩА ВИКЛАДАЧА ЗАКЛАДУ ВИЩОЇ ОСВІТИ
}

У статті розглянуто окремі аспекти життєдіяльності викладача закладу вищої освіти в контексті використання арт-терапї як засобу створення сприятливого професійного середовища. Висвітлено сутність понять "арт-терапія", "функиії арт-терапії". Окреслено иляхи трансформації особистісних переживань у прочес творчої діяльності. Розкрито сутність психотерапевтичної, діагностичної, розвиваючої функцій арт-терапії.

Ключові слова: творча діяльність, функиії та види арт-терапї̈, арт-техніки.

Постановка проблеми у загальному їі вигляді та ії зв'язок із важливими науковими і практичними завданнями. Соціально-економічні, політичні, організаційні суперечності, що виникли в умовах спроб реформування вищої освіти загалом та конкрентних іiі установ зокрема, позначаються, передовсім, на статусі науковця як представника вразливої верстви населення. На широкому тлі негативних трансформацій моральних загальнолюдських цінностей, різкого зниження соціального статусу викладача закладу вищої освіти (фахового, професійного, особистісного тощо) збільшується кількість тих, хто не відчуває своєї професійної і людської значущості, знаходиться в стані деморалізації, втрати життєвих орієнтирів, дезадаптації, що може призвести до зниження рівня професійної діяльності, а також психічних порушень, проявів загальної апатії, професійного вигоряння, зневіри, підвищеної дратівливості тощо. Зважаючи на неможливість дієвого впливу на системні негативні явища у сфері вищої освіти та особливості інтелектуальної діяльності зазначеної категорії працівників, виникає гостра потреба у застосуванні відповідних психолого-педагогічних засобів, одним із яких є, на нашу думку, арттерапія, яка допомагає подолати психологічні проблеми, відновити емоційну рівновагу, поповнити життєву енергію тощо, а також урізноманітнити професійну діяльність у вищій школі.

Аналіз основних досліджень і публікацій із зазначеної проблеми. Роль арт-терапії в процесі соціалізації особистості та відновленні суспільно значущих навичок життєдіяльності стала предметом розгляду багатьох науковців у галузі психології, психотерапії, соціальної педагогіки (Р. Гудман, Х. Рід, Е. Крамер, Д. Лауб, Л. Лєбєдєва, М. Наумбург, Д. Подель, К. Роджерс, К Тисдейл, Д. Уеллєр та ін.) Проте дотепер залишається мало дослідженою роль арт-терапії в ресоціалізації дорослої людини, зокрема, тої, що здійснює професійну діяльність в найскладнішій системі "людина-людина".

У представленій статті маємо на меті довести значення та роль арт-терапії в подоланні дезадапійних процесів у зазначеної категорії фахівців. Заявлена мета передбачає реалізацію наступних завдань: розкриття сутності поняття "арт-терапія"; окреслення завдань арт-терапії в сфері професійнопедагогічної діяльності; визначення можливостей арт-терапії та арт-терапевтичних технік для збереження психічного здоров’я викладачів закладів вищої освіти.

Виклад основного матеріалу з обгрунтуванням отриманих результатів. Як галузь теоретичних та практичних знань арт-терапія сьогодні тлумачиться як міждисциплінарна галузь теорії і особливого виду практики, складовими якої є творчість, лікування, наука, мистецтво тощо. Варто зазначити, що сучасне розуміння арт-терапії пов'язане із визначенням iї як засобу психічної гармонізації, розв'язання соціальних та особистісних конфліктів, що стало результатом іï розвитку як самостійного напряму в лікувально-реабілітаційній, педагогічній та соціальній роботі, починаючи з середини і ХХ століття. Сьогодні науковці звертаються до спостерігаємо тлумачення терміна "арт-терапія" (терапія мистецтвом) як: способу вільного особистісного самовираження (започатковано А. Хіллом у 1938 році) [1:3], як використання засобів мистецтва для трансформації почуттів та інших проявів психіки людини 3 метою зміни структури їі світосприйняття (за М Лібманом) [2: 8]. Теоретичним підгрунтям арт-терапії вчені вважають психоаналітичні ідеї 3. Фрейда та К. Юнга, які у власній психотерапевтичній практиці розглядали іiі як один із методів художньої творчості, реалізація якого забезпечувала можливість психічно хворим виразити в картинах свої приховані психотравмуючі переживання і таким чином позбавитися їх [3: 25]. У психотерапевтичній енциклопедії зазначено, що "арт-терапія це способи і технології реабілітації людини засобами мистецтва і художньої діяльності." [4: 34].

У сучасній науково-педагогічній інтерпретації йдеться про піклування i захист емоційного самовідчуття та психологічного здоров'я особистості або групи осіб засобами творчої діяльності. У контексті досліджуваної проблеми важливим є врахування того, що завдячуючи своєрідній символічній формі (через малюнок, музику, гру, казку тощо) сучасна людина, яка постійно знаходиться в 
агресивному інформаційному, політичному, економічному, екологічному тощо середовищі, може знайти вихід власним бурхливим емоціям, напруженим переживанням, здобути новий соціально значущий досвід у проживанні конфліктних та психотравмуючих ситуацій. Трансформуючи власні переживання у процес творчої діяльності (від споглядання, слухання, естетичного задоволення до малювання, ліплення, вишивання, різьблення тощо) людина отримує можливість крізь призму ірраціонального переглянути власні погляди на самого себе, інших людей, сенс буття загалом. Окрім того, саме в процесі творчої діяльності виникає почуття емоційної насиченості, естетичного задоволення, рівноваги, що гармонізує світосприйняття особистістю їі внутрішнього світу та об’єктивних суспільних чинників.

Психологічне напруження професійної діяльності викладача, науковця, людини інтелектуальної сфери діяльності спонукає звернення до творів мистецтва, які впродовж усієї історії становлення та розвитку цивілізації ставали яскравим відображенням людських мрій, бажань і пристрастей, величних подвигів і перемог, а також глибоких розчарувань і трагічних втрат. Варто також зазначити, що творча діяльність у процесі заняття певним видом мистецтва слугує засобом психологічного і духовного відродження людини, що передбачає подолання психологічної напруги і стресів, забезпечує реалізацію фасилітативної функції у вирішенні спектра соціально та особитісно значущих проблем, створює сприятливі психологічні умови для душевного комфорту, наповнення життєвою енергією тощо.

Можна стверджувати, що сьогодні арт-терапія використовується практично у всіх сферах людської життєдіяльності, зокрема, психології, педагогіці, соціальній роботі, управлінні, бізнесі тощо. Використання методики арт-терапії для відновлення життєвих сил людей напруженої інтелектуальної праці за практичної відсутності вільного часу і матеріального ресурсу (для реалізації, наприклад, туризму, коштовного відпочинку або лікування) забезпечується трансформацією внутрішнього "Я" людини у візуальні, матеріалізовані, символічні образи або специфічні конструкти художньої творчості, коли вона пише картини, вишиває, малює, ліпить, створює скульптуру тощо. Психологи стверджують, що образи художньої творчості відображають зміст підсвідомих процесів, включаючи внутрішні конфлікти, страхи, нав'язливі думки, спогади дитинства, сновидіння тощо. А з огляду на те, що арттерапія не вимагає спеціальних здібностей і художніх навиків, вона може слугувати практично кожній людині. Особливо важливим це $\epsilon$, на нашу думку, для викладача-науковця, який постійно потребує мобілізації творчого потенціалу, активізації механізму психічного імунітету, що, у свою чергу, забезпечує процеси саморегуляції, позитивне наповнення життєдіяльності. Так, у процесі творчої роботи наше підсвідоме через створювані художні образи взаємодіє із свідомістю, а сам процес приносить задоволення, навчає більш довільно і спонтанно виражати свої переживання. Мистецтво у зазначеному контексті визнається ефективним засобом трансформації у завуальованій образній формі проблеми, яка людиною не усвідомлювалася та була витіснена, у малюнок, фігуру, скульптуру, картину й інші художні твори, що ніби проявляє їі, виводить назовні, спонукає проаналізувати і знайти вирішення.

Таким чином, арт-терапія через створення художнього продукту допомагає людині відчути себе творцем, сприяє підвищенню особистісної самооцінки, навчає звільнятися від стереотипів, негативних емоцій та думок, дозволяє розкрити внутрішній потенціал, активізувати життєві сили. Для професійної діяльності викладачів важливими є сформовані на достатньому рівні вміння моделювання способів вирішення складних життєвих ситуацій, екстраполяції їх у реальність, застосування нових соціальних навичок для налагодження професійних взаємовідносин. Заняття атр-терапіїю часто призводить до більш глибокого усвідомлення психологічних причин тих деструкцій, які змушують переживати дискомфорт, стреси тощо [5: 28].

Практичний досвід взаємодії з науковцями закладів вищої освіти, опитування викладачів психологопедагогічних дисциплін дозволяе стверджувати, що до зазначеного методу надання самостійної психологічної допомоги, де твори мистецтва або сам процес їх творення використовується як своєрідний терапевтичний фактор для передачі людських емоцій та почуттів, різноманітних проявів психічної діяльності людини, звертаються більше двох третини опитаних. Так, респонденти зазначали, що використання арт-терапії дозволяє: розвивати, а також відновлювати соціально значущі навички; забезпечує взаємопідтримку і відновлення взаєморозуміння у процесі групової роботи; модифікує й урізномінітнює рольову поведінку, що позитивно впливає на взаємини $з$ колегами, студентами тощо, підвищує самооцінку і призводить до усвідомлення і зміцнення особистої ідентичності, розвиває навички прийняття рішень.

У цьому контексті варто зауважити про переваги групової арт-терапії, до яких можна віднести:

- створення особливої "демократичної" атмосфери, що забезпечується рівними партнерськими відносинами у групі;

- консолідовану відповідальність за результати праці всіх учасників;

- $\quad$ реалізацію певних комунікативних навичок і здатності адаптуватися до групових "норм" [6: 28].

Дослідження, проведені сучасними науковцями, засвідчують, що арт-терапевтичні заняття дозволяють реалізовувати важливі психолого-педагогічні функції [7], що реалізовуються у процесі професійної діяльності викладача. Охарактеризуємо їх більш детально, виходячи із заявленої 
проблематики. Отже, провідною будемо вважати корекційну функцію арт-терапії 3 огляду на ії значущість у процесі відновлення деформованого образу "Я" у напрямі підвищення самооцінки особистості, уникання неадекватних деструктивних виявів поведінки, налагодження способів взаємодії 3 колегами, студентами, членами родини тощо. Необхідність систематичного корегування емоційновольової сфери особистості викадача детермінується і специфікою його професійної діяльності, $\mathrm{i}$, як правило, високим рівнем емпатії, а також особливостями полярних переживань, характерних для стенічних (тих, що спонукають до активності) та астенічних (що пригнічують людину, послаблюють активність, деморалізують їі прагнення) емоцій і почуттів. Зазначимо також, що викладацька діяльність, що передбачає спілкування з широким колом слухачів, студентів тощо вимагає контролю загального емоційного стану, який визначає, забарвлює професійну активність і має носити позитивний, життєстверджуючий характер.

Психотерапевтична функція арт-терапії забезпечує, так званий, лікувальний ефект, який досягається завдяки створенню у процесі творчої діяльності атмосфери емоційної теплоти, доброзичливості, емпатійного спілкування, визнання цінності особистості іншої людини, турботи про неї, іiі почуття, переживання. Індивідуальні заняття арт-терапією, а також використання іiі в процесі підготовки майбутніх фахівців (у нашому випадку йдеться про предстаників педагогічних спеціальностей), дозволяє створити ситуацію психологічного комфорту, захищеності, радості, успіху, а також запобігти маніпулятивному впливу щодо обезцінювання результатів професійної діяльності.

Важливою для ефективної реалізації професійної діяльності вважаємо і діагностичну функцію арттерапії, реалізація якої забезпечує отримання, критичний аналіз інформації про стан, розвиток, індивідуальні особливості психічного розвитку особистості, що знаходиться в системі "людина-людина". Зазначене забезпечується можливістю спостереження за власною діяльністю, що може виявити неочікувані для самої людини інтереси, цінності, схильності і задатки, заглибитися у свій внутрішній світ, а також виявити проблеми, які вимагають спеціальної корекції. Так, у процесі групових занять занять арт-терапією легко виявляються характер міжособистісних відносин і реальне становище кожного в колективі, особливості сімейної ситуації,внутрішні глибинні проблеми особистості.

Розвиваюча функція арт-терапії реалізовується шляхом використання різних форм художньої експресії. Заняття різними видами арт-терапії, що відповідають різновидам мистецтва (власне арттерапія, музикотерапія, танцювальна терапія, драмотерапія, казкотерапія, бібліотерапія, маскотерапія, етнотерапія, ігротерапія, кольоротерапія, фототерапія, лялькотерапія, оригамі тощо), а також застосування арт-терапевтичних технік для вирішення внутрішніх і міжособистісних конфліктів, складних ситуацій, вікових криз, травм, невротичних і психосоматичних розладів тощо забезпечує особистісне зростання представників педагогічних професій в умовах переживання ситуації успіху, естетичної насолоди, вербалізації емоційних переживань, що забезпечує, у свою чергу, набуття досвіду нових форм діяльності, розвиток здібності до творчості, саморегуляції почуттів і поведінки [7: 318].

Висновки та перспективи подальшого дослідження проблеми. Професійно-педагогічна діяльність викладача закладу вищої освіти у сучасних умовах $\epsilon$ складним діалектичним процесом, в якому вазаємодія із суспільством, різними його стратами породжує низку суперечностей соціального та особистісного характеру, внаслідок чого домінує той чи інший тип взаємин між людиною і суспільством. Співвідношення соціального й індивідуального сьогодні визначає певну орієнтацію людини на пріоритет особистих інтересів, задоволення яких є беззаперечною складовою суспільних домагань, які закономірно формуються в процесі соціалізації особистості. Арт-терапія у зазначеному контексті окреслюється науковцями і викладачами-практиками як ефективний спосіб "соціального лікування" особистості, зміни усталених стереотипів поведінки у процесі творчої діяльності. Професійно-педагогічна діяльність як одна із найбільш складних у системі "людина-людина" вимагає зверення іiі представників як до візуалізованих видів творчості (живопис, графіка, фотографії, малювання, ліплення тощо), так i різноманітних методів і технік (казкотерапія, ізотерапія, орігамі та піскова терапія, музикотерапія, маскотерапія, драмотерапія, кольоротерапія, ігротерапія тощо), що дозволяє підвищити рівень життєдіяльності та продуктивності, подолати життєві кризи, набути нового соціально значущого досвіду переживання стресових ситуацій і конфліків.

Використання арт-терапевтичних технік в роботі майбутніми фахівцями вимагає, на нашу думку, особистого володіння ними та допомагає налагодити ефективну комунікативну взаємодію зі студентами в ході творчої діяльності, визначити їхні домінуючі потреби та інтереси, діагностувати їх емоційний, психічний стан, побудувати процес професійної підготовки на основі принципів глибокої поваги до особистості.

\section{СПИСОК ВИКОРИСТАНИХ ДЖЕРЕЛ ТА ЛІТЕРАТУРИ}

1. Титаренко О. І. Використання арт-терапії в психолого-педагогічному супроводі освітнього процесу [Електронний pecypc] $/$ O. І. Титаренко. http://virtkafedra.ucoz.ua/el_gurnal/pages/vyp6/tytarenko.pdf.

2. Копытин А. И. Основы арт-терапии / А. И. Копытин. - СПб. : "Лань", 1999. - 256 с. 
3. Лебедева Л. Д. Практика арт-терапии: подходы, диагностика, система занятий / Л. Д. Лебедева. - СПб. : Речь, 2003. -256 с.

4. Психотерапевтическая энциклопедия / [под. ред. Б. Д. Карвасарского]. - СПб. : Питер, 2000. - 1024 с.

5. Лебедева Л. Д. Арт-терапия в педагогике / Л. Д. Лебедева // Педагогика. - 2000. - № 9. - С. $27-34$.

6. Практикум по арт-терапии / [под ред. А. И. Копытина]. - СПб. : Питер, 2000. - 448 с.

7. Лебедева Л. Д. Педагогические основы арт-терапии в образовании : [монография] / Л. Д. Лебедева. - СПб. : ЛОИРО, 2001. - С. 318.

\section{REFERENCES (TRANSLATED \&TRANSLITERATED)}

1. Titarenko O. I. Vikoristannya art-terapiyi v psihologo-pedagogichnomu suprovodi osvitnogo protsesu [Use of Art Therapy in Psychological and Pedagogical Accompaniment of Educational Process] [Elektronnyi resurs] / O. I. Titarenko. - Rezhim dostupu : http://virtkafedra.ucoz.ua/el gurnal/pages/vyp6/tytarenko.pdf.

2. Kopytin A. I. Osnovy art-terapii [Fundamentals of Art Therapy] / A. I. Kopyitin. - SPb. : "Lan", 1999. - $256 \mathrm{~s}$.

3. Lebedeva L. D. Praktika art-terapii: podhody, diagnostika, sistema zanyatii [Practice of Art Therapy: Approaches, Diagnostics, Occupation] / L. D. Lebedeva. - SPb. : Rech, 2003. - 256 s.

4. Psihoterapevticheskaya entsiklopediia [Psychotherapeutic Encyclopedia] / [pod. red. B. D. Karvasarskogo]. - SPb. : Piter, 2000. - $1024 \mathrm{~s}$.

5. Lebedeva L. D. Art-terapiia v pedagogike [Art Therapy in Pedagogical Science] / L. D. Lebedeva // Pedagogika. 2000. - № 9. - S. 27-34.

6. Praktikum po art-terapii [Pedagogical Bases of Art Therapy in Education] / [pod red. A. I. Kopytina].

7. Lebedeva L. D. Pedahohicheskiie osnovy art-terapii $v$ obrazovanii [Pedagogical Bases of Art Therapy in Education] : [monohrafiia] / L. D. Lebedeva. - SPb. : LOYRO, 2001. - S. 318.

\section{Яценко С. Л. Арт-терапия как средство гармонизации професссиональной среды преподавателя заведения высшего образования.}

В статье рассмотрены некотрые аспекты жизнедеятельносты преподавателя заведения высшего образования в контексте использования арт-терапии как срества создания благоприятной профессиональной среды. Определено сущность понятий "арт-терапия", "функции арт-терапии.

Охарактеризованы способы трансформации личностниых переживаний в проиесс творческой деятельности. Раскрыта сущность психотерапевтической, диагностической, розвивающей функиий арт-терапии.

Ключевые слова: творческая деятельность, функции и виды арт-терапии, арт-техники.

\section{Yatsenko S. L. Art Therapy as a Way of Harmonization of Higher Education Institution Teacher's Professional Environment.}

The article considers some aspects of higher education institution teacher's life in the context of use art therapy as a means of creating a positive professional environment. The essence of definitions "art therapy", "functions of art therapy" is highlighted. The methods of personal emotional experiences transformation into the process of creative activity are described. It's revealed that scholars and teachers practitioners define art therapy as an effective way of "social treatment" resulting in changing personal stereotypes of behavior while creative activity. Professional-educational work is considered to be one of the most difficult in the "man-man" system, so it makes its representatives to appeal to various types of creative work (painting, graphics, photography, drawing, modeling), various methods and techniques (fairy-tale therapy, isotherapy, origami and sand therapy, music therapy, mask therapy, drama therapy, color therapy, game therapy. It's proved that art activity helps to increase productivity and standard of living, to overcome life crises, to acquire a new socially significant experience of stressful situations and conflicts. The author arrives at the conclusion that the usage of art therapy techniques while working helps to establish effective communicative interaction with students in the course of creative activity, to identify their needs and interests, to diagnose their emotional and psychological state, to build a professional training process on the basis of a deep respect to personality.

Key words: creative activity, functions and types of art therapy, art techniques 